\section{Biology of a Littoral Mite}

DURing my work on the biology of the seashore in East Greenland ${ }^{1}$ I made some biological observations of the large, bright red littoral mite (Molgus littoralis L.); its distribution is almost circumpolar, especially on the shores of the more northern regions. In East Greenland it was commonly met with on the shore, but extending its domain beyond the shore, being found (also the eggs) up to an altitude of $120 \mathrm{~m}$., most often in sandy and gravelly places. Trägårdh (p. $\left.419^{2}\right)$ has recorded this and explains it by the non-occurrence of big competing mites. In southern Spitsbergen, it seems to be a strictly littoral form; but in northern Spitsbergen (Low Island, c. lat. $80^{\circ} \mathrm{N}$. ; Hinlopen Strait) it also extends to the "fjœldmark", which is beyond the shore (Summerhayes and Elton, p. 250) ${ }^{3}$.

According to the statements of Sig Thor (p. 97 $)^{4}$, in southern Spitsbergen (Hornsund), more than one generation seems to develop in the year. This does not hold good for the species in East Greenland. June 25 (at Eskimonœes, lat. $74^{\circ} 05^{\prime}$ N.), the snow having recently melted, I found eggs in abundance (in good agreement with the figures given by Trägårdh (p. 10, tab. I, figs. I-2) ${ }^{5}$.) They were found especially on the dry sandy shore, in dense cakes under almost every flat stone. Some of the eggs had not hatched, and others were just hatching, the larvæ swarming over the shore. They only had three pairs of legs. Adult individuals were definitely not found. Later in the summer, also in the other localities I visited, only empty egg-clusters and adult individuals were found. So there can be no doubt that the species in East Greenland only winter in the egg. The difference in behaviour from that in Spitsbergen is possibly due to the more severe climatic conditions.

Molgus littoralis is probably feeding especially upon Collembola ; though I have seen it suck out the shore fly, Fucellia ariciformis, also gnats and even individuals of the same species.

\section{Holger Madsen.}

State Veterinary Serum Laboratory, Copenhagen.

${ }^{2}$ Madsen, Holger, Medd. om Grönl., 100, Nr. 8 (1936).

${ }^{2}$ Trägårdh, J., Medd. om Grönl., 43 (1917).

summerhayes and Elton, J. Ecology, 16 (1928).

4 Thor, Sig, Skrifter om Svalbard og Ishavet, No. 27 (1930).

5 Trägårdh, Bih. K. Svenska Vet. Akadl. Hand., 26, Afd. IV, No. 7 (Stockholm, 1900).

\section{Effect of Unilateral Elimination of the Horizontal Semicircular Canal in the Pike}

IN a recent publication ${ }^{1}$ it was shown that in the dogfish the sense organ situated in the ampulla of the horizontal semicircular canal is in a constant state of excitation. This activity is maintained in the resting animal in the absence of any obvious external stimulus. The result raises the question as to whether the inflow to the centre of the spontaneous discharge from the ampullary sense ending has any noticeable effect on muscle tone.

In order to investigate this, the horizontal semicircular canal of the pike (Esox lucius) was eliminated by severance of the nerve branch supplying the ampulla. The operative technique used in the experiments permitted the elimination of a single canal without any damage to the rest of the labyrinth.
A fish in which the left horizontal canal has been eliminated shows a persistent tonic deviation of the eyes towards the side of the eliminated canal, that is, the left eye is deviated backwards and the right eye forwards. This deviation is obviously due to the inflow to the centre of the spontaneous afferent discharge from the remaining right horizontal canal, which is no longer counterbalanced by a similar discharge from the corresponding left canal. The asymmetry in eye muscle tone which causes the forced deviation of the eyes clearly indicates a tonic function of the horizontal semicircular canals.

During clockwise rotation in the horizontal plane, that is, during rotation of the fish towards the side of the intact right canal, the eye deviation is increased and a normal horizontal eye nystagmus follows. During anticlockwise rotation the spontaneous eye deviation is abolished, that is, the eyes return to their normal positions. These eye responses are in full accord with the behaviour of the ampullary sense organ as studied in the dogfish, where the spontaneous activity of the ampulla of the horizontal canal is increased by ipsilateral rotation (that is, rotation towards the side of the intact canal) and decreased by contralateral rotation.

It is of interest that during contralateral rotation the eyes not only return to their normal position but also continue to deviate beyond the 'neutral' point in a way which is characteristic of the slow phase of the eye respunse of the normal animal during rotation in the same direction. This shows that the centre is capable of responding to a decrease in afferent discharge with the production of a compensatory eye reflex.

The conclusion is therefore justified that a single horizontal semicircular canal in fishes is sufficient to call forth muscular responses to both clockwise and anticlockwise rotation in a horizontal plane. It should be noted that the reflex tests were carried out with exclusion of visual orientation.

A full account of this work will be published in the Journal of Experimental Biology.

Zoology Department,

University of Birmingham. March 18.

'Löwenstein, O., and Sand, A., J. Exp. Binl., 13, 416 (1936).

\section{Anomalous Expansion of Zinc and Cadmium near the Melting Point}

THE expansion of bismuth, as was shown by Roberts $^{1}$ decreases rapidly near the melting point. This anomaly coincides with the anomalous decrease of volume of bismuth on melting.

The expansion coefficients of monocrystals of zinc and cadmium have been measured in order to ascertain whether the anomaly found by Roberts for bismuth occurs with these metals also, and whether the sign of the anomaly coincides with that of the normal change of volume in melting.

In directions nearly parallel or perpendicular to the hexagonal axis, the expansion of zine crystals increases rapidly between $c$. $415^{\circ} \mathrm{C}$. and the melting point $\left(419.5^{\circ} \mathrm{C}\right.$.). In the neighbourhood of $418^{\circ}-419^{\circ} \mathrm{C}$. (near the limit set by the plastic deformation under its own weight) values of the expansion coefficients reaching $50-100 \times 10^{-5}$ (Fig. $1 a$ ) were observed. 